Article

\title{
Discerning Différance in Jacques Derrida's Ethics of Hospitality
}

Franz Joseph C. Yoshiy II

\begin{abstract}
The question of hospitality is not alien to philosophy. It is one of the themes explored by philosophers since the time of Hobbes. Likewise, it was a subject thoroughly discussed by French philosopher Jacques Derrida (1930-2004) in some of his books and seminars. Though more prominently known for his deconstruction and textual analysis, Derrida never failed to address the issues on the hospitality during his time. In fact, he never saw his philosophical work divorced from his ethico-political positions. One of the primary notions associated with his deconstruction (of metaphysics/ logocentrism/ phonocentrism) is différance. At first glance, it appears to have no relation to the ethical-political concern that Derrida has demonstrated in works on hospitality. As a concept, différance seems to dissolve the most inherent tendency in Western metaphysics and philosophy i.e. the logocentric-binary structures. However, my aim is to show that différance may be discerned as a movement inhabiting the tensions within the ethics of hospitality: (1) between the laws of conditional hospitality and unconditional hospitality; and (2) the self-interruption of the subject of hospitality [as host and hostage].
\end{abstract}

Keywords: Derrida, différance, ethics and politics, hospitality

\section{Introduction}

$t$ the advent of the $21^{\text {st }}$ century, crisis in global politics has intensified
with the increased terrorist violence in various parts of the world.
For example, the violence perpetrated by the Islamic State (ISIS) caused the death of millions of civilians in the Middle East. Likewise, this triggered a sudden surge of Middle Eastern refugees seeking asylum in other countries. Based on the numbers given by the International Office of 
Migration, "over 700,000 migrants have arrived by sea into Europe in 2015."1 Though many western countries have already accepted refugees, the recent and controversial bombing and killing in Paris by some Islamic radicals confronted the whole world with the question on the extent of one's hospitality to them. ${ }^{2}$ One might discern an ethical imperative to a refugee by way of hospitality. However, this is no longer a simple question of ethics. Accepting a foreign refugee, may entail socio-political and economic risks.

The question of hospitality is not alien to philosophy. It is a theme discussed since the time of Thomas Hobbes ${ }^{3}$ and Immanuel Kant. ${ }^{4}$ Likewise, it was a subject thoroughly discussed by the French philosopher, Jacques Derrida (1930-2004). Though more prominently known for his deconstruction and textual analysis, Derrida never failed to address the issues on hospitality during his time. In fact, he never saw his philosophical writings divorced from his ethico-political positions. ${ }^{5}$ His engagement in the question of hospitality began after his involvement with the issue of the illegal

${ }^{1}$ Karen Bravo, "Do refugees have a 'right' to hospitality?" in The Conversation (5

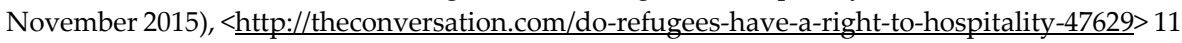
May 2016.

${ }^{2}$ An example of this situation took place after the news of the bombings in Paris last 13 November 2015 reached the United States. "Nothing has yet been confirmed and a massive investigation into the Paris attacks is still ongoing, but the mere possibility that terrorists might be posing as helpless refugees has led to a contentious debate over whether the United States should move forward with President Obama's plan to accept 10,000 new Syrian refugees in 2016." Evan Bonsall, “Are Syrian Refugees Really a Security Risk?" in Harvard Political Review (11 December 2015), <http://harvardpolitics.com/united-states/syrian-refugees-really-securityrisk/>, 11 May 2016.

${ }^{3}$ Haig Patapan traces the roots of modern hospitality from political philosopher Thomas Hobbes (1588-1679). Patapan argues that Hobbes' admiration for Sidney Godolphin initiated him to dream of protecting "noble and law-abiding citizens ... who are willing to sacrifice their lives for their country." Moreover, according to him, Hobbes aimed at crafting 'new human beings' (Leviathan's children) who recognizes other citizens' right of liberty by abandoning their prideful aim for authority, riches and honor. This, for him, is the 'new hospitality' that Hobbes successfully introduced - a "state that allows them [Leviathan's children] to exercise their liberty in peace and prosperity at home and internationally." Haig Patapan, "Leviathan's Children: On the Origins of Modern Hospitality," in Hospitality and World Politics, ed. by Gideon Baker (New York: Palgrave-Macmillan, 2013), 35.

${ }^{4}$ In the 'Third Definitive Article' of Kant's Towards Perpetual Peace, Kant tells us that the 'Cosmopolitan Right Shall be Limited to the Conditions of Universal Hospitality' where the law of hospitality is limited to a 'right of resort (or visit)' based on one's cosmopolitan right i.e. the right that pertains to humanity's 'common possession' of the earth. Hence, a guest may not ask for more from the state (e.g. citizenship) other than one's right to visit. Cf. Immanuel Kant, Perpetual Peace, in Political Writings, trans. by H.B. Nisbet and ed. H.S. Reiss (New York: Cambridge University Press, 1991), 106.

${ }^{5}$ In an interview with Antoine Spire in 2000, Derrida states that "I don't feel a divorce between my writings and my engagements, only differences of rhythm, mode of discourse, context, and so on." Jacques Derrida, Paper Machine, trans. by Rachel Bowlby (Stanford: Stanford University Press, 2005), 153.

(c) 2017 Franz Joseph C. Yoshiy II

https://www.kritike.org/journal/issue 21/yoshiy december2017.pdf

ISSN 1908-7330 


\section{DIFFÉRANCE IN DERRIDA'S ETHICS OF HOSPITALITY}

immigrants. ${ }^{6}$ He deplored the fact that European countries, like France, "are turning their borders into new iron curtains" 7 by promulgating "a law permitting the prosecution, and even the imprisonment, of those who take in and help foreigners whose status is held to be illegal." 8 To fully understand his position on ethico-political issues in relation to his philosophical enterprise, I find it necessary to go back to the very root of his philosophical project i.e. his (in)famous deconstruction.

Deconstruction began not only as a critique of Western metaphysics, but also as a critique against the tradition of everyday thought and language of the West. ${ }^{9}$ This was Derrida's response to the prevailing temperament of Western thought which is constructed in terms of opposites or dichotomies: being/non-being, identity/difference, soul/body, presence/absence, man/woman, speech/writing. Derrida's problem, however, is not that these terms are opposed to each other, but that they are seen in a hierarchical fashion. The positive term (being, identity, soul, presence, speech, man) is privileged and placed over the underprivileged negative term (non-being, difference, body, absence, writing, woman).

Derrida, however, saw a gap within this binary structure. In $O f$ Grammatology, deconstruction works within the opposition of speech and writing. Speech (or phonocentrism) is privileged because of the assumption that it is nearer to being/meaning of being/ideality of meaning. ${ }^{10}$ When one speaks, the assumption is that one is expressing the 'full presence' of meaning - that there is no breach or gap between our intention to mean and

${ }^{6}$ See Bennoît Peeters, Derrida: A Biography, trans. by Andre Brown (Malden: Polity Press, 2013), 469.

7 Jacques Derrida, "Derelictions of the Right to Justice," in Negotiations: Interventions and Interviews, 1971-2001, ed. and trans. by Elizabeth Rottenberg (Stanford: Stanford University Press, 2002), 134.

${ }^{8}$ Ibid., 133.

${ }^{9}$ Cf. Barbara Johnson, Translator's Introduction to Dissemination by Jacques Derrida, trans. by Barbara Johnson (London: The Athlone Press, 1981), viii. Martin Heidegger (1889-1976), who also influenced Derrida, criticized the Western mode of thinking and behavior as well. in Being and Time (1927), Heidegger deplored the domination of ontology over the history of western culture. He points out that the static and transcendental plane of ontology forgets the very "there-ness" of being (hence, the central notion in his work is the Da-sein or 'being-there'). Cf. Martin Heidegger, Being and Time, trans. by John Macquarie and Edward Robinson (Oxford: Blackwell Publishers, 1962) §6, pp. 41-49. Hence, it is from Heidegger where one is acquainted with one of the important gestures of Derrida's deconstruction i.e. "The Task of Destroying the History of Ontology."

${ }^{10}$ Derrida underscores the connection between phonocentrism and logocentrism by saying that 'within the logos, the original and the essential link to the phonè has never been broken ... the essence of the phonè would be immediately proximate to that which within "thought" as logos relates to "meaning," produces it, receives it, speaks it, "composes" it. Cf. Jacques Derrida, Of Grammatology, corrected ed., trans. by Gayatri Chakravorty Spivak, (Baltimore: The John Hopkins University Press), 11-12. Emphasis mine.

(C) 2017 Franz Joseph C. Yoshiy II

https://www.kritike.org/journal/issue 21/yoshiy december2017.pdf

ISSN 1908-7330

(cc) BY-NC-ND 
what we utter in and through the signs of the linguistic system or a particular language. As Christopher Norris remarks "the logocentric will [is] to privilege a self-present (spoken) truth above the endless duplicities of written language. This idea is one that Derrida sought to deconstruct by all manner of graphic and rhetorical means."11 And, one of these strategies is différance.

At first glance, différance appears to have no relation to the sorts of ethical-political concern that Derrida has demonstrated in works on hospitality. As a concept, it seems to dissolve the most inherent tendency in Western metaphysics and philosophy i.e. the logocentric-binary structures. However, my aim is to show that, in fact, différance may be discerned as a movement inhabiting the tensions within the ethics of hospitality: (1) between the laws of conditional hospitality and unconditional hospitality; and (2) the self-interruption of the subject of hospitality [as host and hostage].

In order to do so, I shall first go back to Derrida's notion of différance as expounded in his 1968 lecture, "La Différance" then, I shall elaborate on his ethics of hospitality through his 1997 Istanbul lecture, "Hostipitality" with occasional references to his other writings on hospitality.

\section{Derrida's Différance}

In 1967, Derrida's three important works: Voice and Phenomenon, Writing and Difference and Of Grammtology were published. He introduced his neologism différance in these works. The year after these three important writings appeared, on 27 January 1968, he delivered "La Différance" to the Société française de philosophie. ${ }^{12}$

Différance is a deliberate "misspelling" of the French word différence. Since in French, both words have similar pronunciations, one can never know the phonic difference between différance and difference. One cannot hear the difference between these two; it is mute, it is silent. And for Derrida, this "silence of the graphic difference between the $e$ and the $a$ can function, of course, only within the system of phonetic writing, and within the language and grammar which is as historically linked to phonetic writing as it is to the entire culture inseparable from phonetic writing." 13 By changing the $e$ into $a$, he is deconstructing one of the major logocentric binaries of philosophy: phonetic writing (speech) and graphic writing (writing).

\footnotetext{
${ }^{11}$ Christopher Norris, Derrida (Cambridge, MA: Harvard University Press, 1987), 63.

12 This lecture would eventually be published in Bulletin de la Société française de philosophie (July-September 1968). Jacques Derrida, "Différance" in Margins of Philosophy, trans. by Alan Bass (Great Britain: The Harvester Press, 1982), 1-27.

${ }^{13}$ Ibid., 4.
}

(C) 2017 Franz Joseph C. Yoshiy II

https://www.kritike.org/journal/issue 21/yoshiy december2017.pdf

ISSN 1908-7330 


\section{DIFFÉRANCE IN DERRIDA'S ETHICS OF HOSPITALITY}

Derrida, however, does not give a clear-cut definition of différance. Instead, he tries to show how the various directions of this non-concept and non-word is built into a sheaf. Even though this is the case, he gives us a rough and simple semantic examination of it. The French verb différer (coming from the Latin verb differre) can mean two things. On the one hand it can mean:

the action of putting off until later, of taking into account, of taking account of time and of the forces of an operation that implies an economical calculation, a detour, a delay, a relay, a reserve, a representationconcepts that I would summarize here in a word I have never used but that could be inscribed in this chain: temporization. ${ }^{14}$

On the other hand, it can also mean:

to be not identical, to be other, discernible, etc. When dealing with differen(ts)(ds), a word that can be written with a final ts or a final $d s$, as you will, whether it is a question of dissimilar otherness or of allergic and polemical otherness, an interval, a distance, spacing, must be produced between the elements other, and be produced with a certain perseverance in repetition. ${ }^{15}$

In short, différer means "to defer" (first sense) or "to differ" (second sense). Derrida notes that since the word différence cannot take its meaning from either of these two aforementioned senses, différance can refer to both senses at the same time.

The translator of Derrida's lecture "Différance" explains that the French word différence does not suggest "to defer" (the act of putting off later/postponement) or "to differ" (just as when one says, "I beg to differ"). ${ }^{16}$ The word simply signifies difference. For example, "There is a difference between A and B." The verb différer when conjugated into the present participle, turns into différant. Here, the translator remarks "Curiously then, the noun différance suspends itself between the two senses of différant deferring, differing. We might say that it defers differing, and differs from deferring, in and of itself." 17 Now it is clear why Derrida mentions that

\footnotetext{
${ }^{14}$ Ibid., 8.

${ }^{15}$ Ibid., See footnote 8. The translator notes that the two French words, "différants" and "différands," sound similarly. Although, the former refers to "different things" while the latter refers to "different opinions".

${ }^{16} \mathrm{Ibid}$., See footnote 9.

${ }^{17}$ Ibid., See footnote 10.

(C) 2017 Franz Joseph C. Yoshiy II https://www.kritike.org/journal/issue 21/yoshiy december2017.pdf ISSN 1908-7330
}

(cc) BY-NC-ND 
différence cannot refer to "to defer/to differ" since it is a noun and it is passive. However, différance "brings us close to the infinitive and active kernel of [the verb] différer." 18 The "-ance" ending in différance is crucial since it suggests that it is an "action" not taken by a conscious subject - e.g. in English we have the term severance. This is not the action of a subject doing something i.e. severing. Rather, it is a "phenomenon" which proffers an undecidability between the active and the passive.

Derrida however poses another problem: how then do we unite the two senses of différance? He continues his semantic examination by referring back to the Swiss linguist, Ferdinand de Saussure. He cites that, for Saussure, the sign is "arbitrary and differential". ${ }^{19}$ Now, the aforementioned linguist asserts that these two cannot be separated. "There can be arbitrariness only because the system of signs is constituted solely by the differences in terms, and not by their plenitude." 20 In other words, the identity of any sign is produced by the differences; it has no singular identity without difference. Derrida stresses Saussure's arbitrary-differential nature of the sign in relation to différance in these following points: (1) Saussure's difference and différance are neither words nor concepts; and (2) différance produces these differences in language. The latter point however bears the most significant aspect as he declares that "we will designate as différance the movement according to which language, or any code, any system of referral, is constituted "historically" as a weave of differences." 21

Derrida also points to Sigmund Freud and Friedrich Nietzsche in order to show that différance is also manifested in some of their works. In congruence with the theme of Nietzsche's philosophy Derrida states that "différance, is the name we might give to the "active" moving discord of different forces, and of differences of forces, that Nietzsche sets up against the entire system of metaphysical grammar..." 22 In addition, Derrida highlights the role Freud plays in his conception of différance by revisiting the latter's notions of trace, breaching, and the opposition between the pleasure and reality principles. Différance is responsible for the production of "unconscious traces" in the "process of inscription." 23 In fact, différance as the "movement of the trace" is what governs the life-preserving mechanism through the deferment of a "dangerous investment" and creates a certain "reserve." This is an illustration of how the economy of différance works within the system of

${ }^{18}$ Ibid., 9.

${ }^{19}$ Cf. Ferdinand de Saussure, Course in General Linguistics, trans. by Wade Baskin and ed. by Perry Meisel and Haun Saussy (New York, NY: Columbia University Press, 2011), 67-70.

${ }^{20} \mathrm{Ibid}$.

${ }^{21}$ Derrida, "Différance," 12. Italics mine.

22 Derrida recalls that the "unconscious" for Nietzsche is "the great principal activity" and that "consciousness" is a product of forces. Ibid., 18.

${ }^{23} \mathrm{Ibid}$.

(C) 2017 Franz Joseph C. Yoshiy II

https://www.kritike.org/journal/issue 21/yoshiy december2017.pdf

ISSN 1908-7330

(cc) BY-NC-ND 


\section{DIFFÉRANCE IN DERRIDA'S ETHICS OF HOSPITALITY}

Freud's concepts: "One is the other in différance, one is the différance of the other." 24

Similarly, Derrida also traces the economy of différance in Emmanuel Levinas' criticism of 'ontology as first philosophy' and his proposal of 'ethics as first philosophy'. Here, Levinas takes his discourse on the level of alterity: the Other. Derrida justified Levinas' position earlier in a 1964 essay "Violence and Metaphysics" wherein "we find discussions both of the difference between the same and other and of the difference between totality and infinity." 25 In the essay, Derrida emphasizes that the ego (same) cannot be itself (or ego as such) if it is not the other's other neither would the alter ego of the ego would be as such if it is not an ego itself. ${ }^{26}$ In this statement, Derrida was trying to say that even Levinas' ethics of alterity cannot escape an ontology/metaphysics of identity - that the experience of other or of difference is always determined by a metaphysics of presence..$^{27}$

Aside from these three mentioned philosophers, Derrida adds Martin Heidegger. The latter's ontological difference [i.e. the difference between Sein (Being) and seiendes (beings)] is unfolded by the mark of $a$ in différance. ${ }^{28} \mathrm{He}$ adds, "Being has never had a 'meaning,' has never been thought or said as such, except by dissimulating itself in beings, then différance, in a certain and very strange way, (is) "older" than the ontological difference or than the truth of Being." 29

\section{Derrida's Ethics of Hospitality}

During the years 1995-1997, Derrida became engaged with the questions on responsibility, particularly with the theme of "hospitality." His seminars on the subject of hospitality is divided into two phases: (I) "Questions of Responsibility: Hostility/Hospitality" (1995-1996); and (II) "Questions of Responsibility: Hostipitality" (1996-1997).30 Two of the lectures

\footnotetext{
${ }^{24} \mathrm{Ibid}$. Details on the relation between Freud and différance is elaborated in Jacques Derrida, "Freud and the Scene of Writing" in Writing and Difference, trans. by Alan Bass (Chicago: University of Chicago Press, 1978), 196-231.

${ }^{25}$ One must remember that Levinas criticized ontology's long-standing emphasis on the same and totality, which are allied concepts of Being. By proposing 'ethics as the first philosophy,' he shifts the focus from Being (same, totality) to the other and infinity. Cf. Robert Bernasconi, "The Trace of Levinas in Derrida," in Derrida and Différance, ed. by David Wood and Robert Bernasconi (Evanston, IL: Northwestern University Press, 1988), 13.

${ }^{26}$ Cf. Derrida, "Violence and Metaphysics: An Essay on the Thought of Emmanuel Levinas" in Writing and Difference, 128.

${ }^{27}$ Cf. Ibid., 152.

${ }^{28}$ Cf. Derrida, “Différance," 22.

${ }^{29} \mathrm{Ibid}$.

${ }^{30}$ The seminars were originally delivered in French with the titles: "Questions de responsabilité V: hostilité/hospitalité" and "Questions de responsabilité VI: hostipitalité." See

(C) 2017 Franz Joseph C. Yoshiy II

https://www.kritike.org/journal/issue 21/yoshiy december2017.pdf

ISSN 1908-7330
}

(c) BY-NC-ND 
from the first phase is published in the book Of Hospitality, where Anne Dufourmantelle engages Derrida into a dialogue. Some of his lecture notes from the second phase are published as 'Hostipitality' in the book Acts of Religion. ${ }^{31}$ My discussion of his ethics of hospitality in this section, however, shall come from his 1997 Istanbul lecture 'Hostipitality' where, "[the] central philosophical argument is clearest" unlike in the two aforementioned works where he focuses his discussion on related texts concerning the stranger, enemy, the host and the guest. ${ }^{32}$

Derrida's lecture begins with a quotation from Immanuel Kant's Towards Perpetual Peace. The "Third Definitive Article of a Perpetual Peace" states that "Cosmopolitan Right shall be limited to the Conditions of Universal Hospitality." 33 Derrida notes that Kant highlights two terms: Cosmopolitan Right and Universal Hospitality. Cosmopolitan Right belongs to the realm of right with respect to citizenship, the State and its subject, world State (international law) and thus is neither concerned with morality nor politics. The latter on the other hand, serves as one of the conditions of the former (that will be ratified in a treaty among States).

The word hospitality is of Latin origin which, according to Derrida, bears its own contradiction. ${ }^{34} \mathrm{He}$ reiterates Kant's emphasis that the article involves right and not philanthropy. ${ }^{35} \mathrm{He}$ underscores Kant's equivalent term for hospitality in German, Wirtbarkeit. ${ }^{36}$ It is derived from the word Wirt ${ }^{37}$ which signifies the host. Thus, Derrida remarks, it is the host, being the master of the household (or the State), who establishes the 'conditions for hospitality.'38 From this, it follows then that there is no room for unconditional welcome.

However, the establishment of the conditions of hospitality breaches the very idea of hospitality with a contradiction. Hospitality is a duty to "welcome the other stranger as a friend but on the condition that the host, the hote, the Wirt, the one who receives, lodges or gives asylum remains the patron,

"Seminars," in Derrida Seminars Translation Project (2009), <http://derridaseminars.org/ seminars.html >, 12 February 2017.

${ }^{31}$ Jacques Derrida, Acts of Religion, ed. by Gil Anidjar (New York: Routledge, 2002).

${ }^{32}$ Cf. Jacques Derrida, "Hostipitality," in Jacques Derrida: Basic Writings, trans. by Barry Stocker and Forbes Morlock, (London \& New York: Routledge, 2007), 239. This English translation of the lecture by Barry Stocker and Forbes Morlock was first published in Angelaki: Journal of the Theoretical Humanities vol. 5, no. 3 (December 2000), 3-18.

${ }^{33}$ Cf. Ibid., 243.

${ }^{34}$ Cf. Derrida, “Hostipitality," 244.

${ }^{35}$ Cf. Ibid.

36 "As in the foregoing articles, we are concerned not with philanthropy, but with right. In this context hospitality means the right of a stranger not to be treated with hostility when he arrives on someone else's territory." Kant, Political Writings, 105.

37 "Wirthin" is the feminine equivalent.

${ }^{38}$ Kant, Political Writings, 245. 


\section{DIFFÉRANCE IN DERRIDA'S ETHICS OF HOSPITALITY}

the master of the household." ${ }^{39}$ In other words, the host maintains his authority over his home by establishing laws that would limit the gift of hospitality offered to the other, so as not to efface his identity and authority as master. According to Derrida, this is the "implosion" or the "autodeconstruction" of hospitality; it is seen as "protecting itself from itself, autoimmunising in some way, that is to say deconstructing itself - precisely - in practicing itself, precisely." 40

"We do not know what hospitality is." [Nous ne savons pas ce que c'est que l'hospitalité]-this was Derrida's inviting statement after his analysis of Kant's third definitive article. But what does he mean by this? To begin with, one must remember that Derrida was addressing his audience in his mother tongue-French. I placed the original French (in brackets) beside the English translation, because Derrida wanted to show his audience that by addressing them in French, the language of his home, he is welcoming, receiving, and inviting them inside his home by allowing them to cross a threshold. ${ }^{41}$ Likewise, by addressing them in such manner, he is asserting his position as the host [hôte], master of the home that welcomes his guest/s [hôte]. ${ }^{42} \mathrm{He}$ supposes that given this setup, I (the host), address and welcome you (the guest), by first of all saying "we do not know what hospitality is." This, however, is a co an aporia, a performative contradiction. ${ }^{43}$ To understand what this means, Derrida presents us with four acceptations.

First, "we do not know what hospitality is." Not knowing hospitality, according to Derrida, does not consist in one's ignorance of the subject matter. It "is not a concept which lends itself to objective knowledge ... hospitality ... is an experience...an intentional experience which carries itself, beyond knowing, towards the other as absolute stranger, as unknown, there where I know that I know nothing of him..."44 In other words, hospitality is an experience of the unknown Other, a total stranger. But then, even if the Other is a stranger, conditions are already stipulated..$^{45}$ At the end, there is still a

${ }^{39}$ Ibid.

${ }^{40} \mathrm{Ibid} ., 246$.

${ }^{41}$ The phenomenon of the threshold (the door or border) is greatly emphasized by Derrida. The threshold for him is where the master (of the home, State, Nation etc.) welcomes the other (the guest or someone seeking asylum) into his/her home by letting him/her pass through it. Cf. Ibid., 248.

${ }^{42}$ As you may have noticed, the French equivalent for the words host and guest/s (in brackets) are the same - hôte. This is a basic ambiguity in the French language for the word hôte may either refer to host or guest.

${ }^{43}$ Cf. Ibid.

${ }^{44}$ Ibid., 250. Italics mine.

45 Cf. Ibid. Derrida clarifies in another work (Of Hospitality) that the foreigner (or stranger) is never simply a total other i.e. someone who is entirely different. Even the foreigner is bound by certain obligations with other men. In other words, hospitality is also a kind of contract - "this contract of hospitality that links to the foreigner and which reciprocally links the foreigner,

(c) 2017 Franz Joseph C. Yoshiy II

https://www.kritike.org/journal/issue 21/yoshiy december2017.pdf

ISSN 1908-7330

(c) BY-NC-ND 
necessity to know everything about hospitality but at the same time, he asks us to think beyond what can be known about it. John Caputo adds that this apparent difficulty in not knowing what hospitality is, is not simply resolved through one's intellectual competence, but also through a generous act, as in gift giving, "[binding] the other to me in gratitude and the need to reciprocate. What is true of hospitality is true, too, of the gift, and of deconstruction itself: it does not come down to knowing anything, but to doing something." 46

Second, "we do not know what hospitality is" signifies that it is what is not. However, Derrida claims he does not mean that hospitality is nothingness, it is indeed something! He places the accentuation on the negative because hospitality is not being (in the strict and metaphysical sense of the term).$^{47}$ Instead, it deals with right, law, duty, obligation, etc. It speaks of a stranger's right to hospitality and the host's duty to provide hospitality. The host as master of the house sets down the laws of hospitality where, according to him, the contradiction within hospitality takes form.

Using Pierre Klossowski's text, Roberte this Evening, Derrida attempts to demonstrate the paradoxes that lie beneath the act of hospitality. On the one hand, he examines the contradiction between the essence and existence of the hostess. Roberte was expecting a guest, while she was in the presence of Octave. The guest enters and comes up behind Roberte. But it was Octave who enters, attempting to surprise Roberte by acting like the guest. Klossowski's novel was drawn into the problem of hospitality while taking account of the sexual difference between the couple, and their relationship to a witness (who is the guest at the same time). Thus, according to Derrida, the contradiction may be found within the "essence of the hostess" (as Klossowski likewise sees it). ${ }^{48}$

On the other hand, Derrida expounds the apparent hostage taking and reversal of roles ${ }^{49}$ between the host and the guest. The host who invites becomes the one invited by the guest. The host becomes hostage to the guest. In this case, Derrida takes hostage to mean "security for an occupation ... a

it's a question of knowing whether it counts beyond the individual and if it also extends to the family, to the generation, to the genealogy." See Jacques Derrida, Of Hospitality: Anne Dufourmantelle invites Jacques Derrida to Respond, trans. by Rachel Bowlby, (Stanford, CA: Stanford University Press, 2000), 21.

${ }^{46}$ Cf. Jacques Derrida, Deconstruction in a Nutshell: A Conversation with Jacques Derrida, ed. by John Caputo (New York, NY: Fordham University Press, 1997), 112. See also pp. 140-151 for Caputo's discussion of The Gift.

${ }^{47}$ He asserts that "[if] we do not know what hospitality is ... it is not a present being." Derrida, "Hostipitality," 251.

${ }^{48} \mathrm{Cf}$. Ibid, 252. Klossowski, in his novel, was trying to uncover the contradiction within the passage.

49 Ibid., 253. Cf. Derrida, Of Hospitality, 129.

(C) 2017 Franz Joseph C. Yoshiy II

https://www.kritike.org/journal/issue 21/yoshiy december2017.pdf

ISSN 1908-7330 


\section{DIFFÉRANCE IN DERRIDA'S ETHICS OF HOSPITALITY}

guarantee for the other, held in place and taking the place." ${ }^{50}$ He further explores the notion of a hostage and hostage taking in relation to ethics and responsibility. Derrida cites Levinas' claim that one is held hostage by the Other when one exercises his/her ethical responsibility. ${ }^{51}$ In addition, he underscores the role played by the "I" by probing into the problem of ipseity. In "Substitution" (from Otherwise than Being, or Beyond Essence), Levinas speaks of the connection between the $I$ (subject) as hostage and responsibility for the other. Derrida quotes Levinas: "Ipseity in its passivity without the arche of identity, is the hostage. The word ' $I$ ' would answer for all and everything." 52

Thirdly, "we do not know what hospitality is," for Derrida would mean "we do not know yet what hospitality is." 53 This third acceptation puts emphasis on the not yet - where a fundamental anachrony is being suggested. This is an implicit reference to Levinas' notion of anachrony in that it exists in the "paradoxical instant" of the subject being the host and hostage at the same time. ${ }^{54}$ The not yet refers to the threshold that is yet to be crossed. From here, Derrida draws our attention to two other reasons regarding the "present future but "not yet"' of hospitality: firstly, because the European system that regulates and limits hospitality via certain rights, laws and politics has a particular history (and Kant already pointed this out in the Third Definitive Article of Perpetual Peace we quoted earlier). As for Derrida, "we do not know what hospitality is" signifies that we do not yet know what it is "beyond this European, universally European right." 55 Secondly, the not yet entails "what remains to come, always in the future, what comes from hospitality, what is called and called by hospitality." 56 This statement leaves us with further several implications and questions: who is going to come? what is going to come? what is called hospitality? what is called in hospitality?

Lastly, Derrida's proposed fourth acceptation for "we do not know what hospitality is" is its double bind (contradiction in movement) or its aporetic condition. Given the foregoing acceptations, Derrida was able tease out certain contradictions and paradoxes through his semantic (etymological and institutional) analyses of some terms belonging to the vocabulary and

50 Taking reference from the Littré, he traces the current usage of the word hostage [otage] from the word ostage that dates back to thirteenth-century texts. The Littré also suggests that it comes from the contracted form of obsidaticum i.e. hostaticum. From obsidaticum, a string of words may be associated: obsudatus ("guarantee"), obsess/obsiditis (was hostage), and obsidere (to occupy, to possess, to obsess). Ibid., 253.

${ }^{51}$ Ibid.

52 Ibid. Cf. Emmanuel Levinas, Otherwise than Being, or Beyond Essence, trans. by Alphonso Lingis, (Dordrecht, The Netherlands: Kluwer Academic Publishers, 1991), 114.

${ }^{53}$ Derrida, "Hostipitality," 254-255.

${ }^{54}$ Cf. Ibid., 254.

${ }^{55}$ Cf. Ibid., 255.

${ }^{56}$ Ibid.

(C) 2017 Franz Joseph C. Yoshiy II

https://www.kritike.org/journal/issue 21/yoshiy december2017.pdf

ISSN 1908-7330

(c) BY-NC-ND 
discourse of hospitality. These contradictions are what constitutes this final and fourth acceptation, its aporia. ${ }^{57}$ In offering hospitality, the host allows the guest to pass through the threshold. But then, he asks, "is it not aporia...the non-passage?" 58 Derrida argues, however, that aporia does not necessarily entail something negative; it as a necessary condition for hospitality or any welcoming. ${ }^{59} \mathrm{He}$ goes on to underscore the paradox which runs through the law of hospitality. First, the host is masculine, the sovereign master of his house i.e. he has an overarching control over his house and the goods that he may offer to a guest. There must be an affirmation of the host over his domain and ownership of the house before he can give it away. He provides hospitality to the guest under the condition that the latter respects the former's being at home, of the host being-himself at home or the laws of hospitality that govern the household. It is here where Derrida points out the self-contradiction in the law of hospitality.

There is no hospitality if there are no doors/thresholds, and yet, there is no hospitality if there are doors. From here, Derrida demarcates the difference between a "hospitality of visitation" and "hospitality of invitation." The former pertains to a hospitality without a door- "anyone who is anyone arrives at any moment and passes without needing a key for the door. The customs are not checked for the visitation." 60 In contrast, the latter means a hospitality with a door, where everyone is checked by the customs and police (or the master himself) before one is allowed to cross.

Derrida cautions us not to think of this contradiction (aporia) within the threshold as hospitality. Instead, he asserts that it is this very aporetic threshold that we must cross. In other words, we must go beyond this contradiction that takes place within the threshold to go beyond hospitality. ${ }^{61}$ For hospitality to be possible, one must perform the impossible. Derrida writes, "[hospitality] can only take place beyond hospitality, in deciding to let it come, crossing the hospitality which paralyses itself on the threshold that it is." 62 Hence, "we do not yet know what hospitality is" means that the kind of hospitality beyond itself is "yet to come" - a future that goes beyond our knowing.

\footnotetext{
${ }^{57}$ Derrida describes an aporia as "not knowing where to go" - which has something to with nonpassage (or its experience), something that holds us back (paralyzes us) before a certain threshold (or border, door, line etc.). Cf. Jacques Derrida, Aporias, trans. by Thomas Dutoit (Stanford, CA: Stanford University Press, 1993), 12.

${ }^{58}$ Cf. Derrida, "Hostipitality," 258

${ }^{59}$ Cf. Ibid.

${ }^{60} \mathrm{Ibid}$.

${ }^{61}$ Cf. Ibid., 261.

${ }^{62} \mathrm{Ibid}$.
}

(c) 2017 Franz Joseph C. Yoshiy II

https://www.kritike.org/journal/issue 21/yoshiy december2017.pdf

ISSN 1908-7330 


\section{DIFFÉRANCE IN DERRIDA'S ETHICS OF HOSPITALITY}

\section{Discerning Différance in Hospitality}

In the second section, we discussed how the movement of différance produces the various oppositions in our language and serves as their common denominator. The discussion on Derrida's hospitality (with the four acceptations as its highlight) in the third section maintains two dilemmas (or as I would like to call them: tensions) that occur in almost every acceptation. These two tensions are: (1) the tension within the contradictory laws of hospitality; and (2) the tension within the subject of hospitality (particularly to that of the host-guest [hotte] relation). Having elaborated on these topics, I shall now attempt to discern the movement of différance within these two tensions scrutinized by Derrida in his discourse on hospitality.

\section{A. Différance within Hospitality: Between Unconditional and Conditional}

Hospitality is an obligation of a State to a certain person seeking asylum or even asserting his right to it. Within this seemingly absolute or categorical (or in Derrida's parlance unconditional) hospitality is a certain condition: the host welcomes the guest under the condition that the guest respects the position and authority of the host as host. But then, the doublemovement of the laws of hospitality comes from the fact that the very law of hospitality dictates that one render hospitality unconditionally (hospitality being an obligation) while at the same time stipulating laws that would limit the hospitality being offered. These two laws are inseparable. In Of Hospitality, Derrida emphasizes this point by saying that despite the irreconcilable tension between the two [laws], this tension is necessary "conditional laws would cease to be laws of hospitality if they were not guided, given inspiration, given aspiration, required, even, by the law of unconditional hospitality." 63

Derrida admits to the radical difference/heterogeneity of the two laws, yet at the same time insists that these two laws cannot be dissociated. ${ }^{64}$ In an interview, he opines on this matter:

I analyse something which is not a simple opposition between the 'unconditional' and the 'conditional'. If the two meanings of hospitality remain mutually irreducible, it is always in the name of pure and hyperbolic hospitality that it is necessary, in order to

${ }^{63}$ Derrida, Of Hospitality, 79.

${ }^{64}$ Cf. Ibid., 147.

(C) 2017 Franz Joseph C. Yoshiy II

https://www.kritike.org/journal/issue 21/yoshiy december2017.pdf

ISSN 1908-7330

(c) BY-NC-ND 
render it as effective as possible, to invent the best arrangements [dispositions], the least bad conditions, the most just legislation. This is necessary to avoid the perverse effects of an unlimited hospitality whose risks I tried to define. 65

In view of the foregoing, I would like to appeal to a basic opposition: that of the conditional and unconditional hospitality. By the virtue of their separate and conflicting movements, one cannot simply reduce them to the other. Yet, as Derrida claims, they cannot be separated from one another i.e. to posit unconditionality would already be breached by conditionality, or to posit conditionality would already be driven by the thought of unconditionality. Hence, we are left in this aporetic crossroads.

But, différance already works within the opposition of conditional and unconditional hospitality. The next question would then be: how do we discern différance within these two oppositions?

Although différance started out as one of Derrida's strategies in undoing logocentrism, later on, he would consider it as the very condition for the possibility of any ethical or political act. ${ }^{66}$ It was discussed in the second section, that différance plays a two-fold signification i.e. "to differ-to defer". In a later interview, on the other hand, when asked by his interlocutor to expound on his "assertion that discourse, knowledge, and therefore moral practice, is a process of endless différance, ${ }^{67}$ Derrida responded by saying:

Turning to the subject of 'endless difference': it is commonplace today to understand différance with an ' $a$ ' as simply postponement which neutralizes decision. This is something which, had some attention been paid to the text in the beginning, could have been overcome. If différance was simply infinite postponement, it would be nothing. If I played on the 'a' of différance, it is in order to keep in a single word two logics: one of the delay, the detour, which implies a process, a strategy or a postponement; and difference with an ' $\mathrm{e}$ ', which implies heterogeneity, alterity and so on. Now, because there is alterity and the other, for example, this cannot wait. There is an unconditional commandment, so to speak,

\footnotetext{
${ }^{65}$ Jacques Derrida, “The Principle of Hospitality" in Parallax 11:1 (2005), 6. Italics mine.

${ }^{66}$ Cf. Jacques Derrida, "Hospitality, Justice and Responsibility: A Dialogue with Jacques Derrida" in Questioning Ethics: Contemporary Debates in Philosophy, ed. by Richard Kearney and Mark Dooley (London: Routledge, 1999), 77.

${ }^{67}$ Ibid., 76.
} 


\section{DIFFÉRANCE IN DERRIDA'S ETHICS OF HOSPITALITY}

not to wait, and it is because there is this possibility of postponing that we can and we must make decisions. If there was no possibility of delay, there would be no urgency either. Différance, therefore, is not opposed to ethics and politics, but is their condition: on the one hand, it is the condition of history, of process, strategy, delay, postponement, mediation, and, on the other hand, because there is an absolute difference or an irreducible heterogeneity, there is the urge to act and respond immediately and to face political and ethical responsibilities. ${ }^{68}$

Following these series of arguments, the movement of différance in the tension between the conditional and unconditional laws may be discerned in the following manner. Firstly, let us take différance as differing in relation to the two laws of hospitality. Différance, in this sense, inhabits the tension in such a manner that both laws are radically different. Their opposition against each other enables us to discern différance as the principle of their differentiation or heterogeneity. There is no difficulty in understanding this since différance "as that which produces different things, that which differentiates ... the common root of all oppositional concepts that mark our language ..." ${ }^{69}$ Hence, it is without doubt that différance as differing would move within the oppositional concept of conditional and unconditional hospitality.

Secondly, taking différance as deferring in relation to both laws, brings us back to the notion of deferral as "postponement," "detour" and "economical calculation."70 Because, there is difference or differing in the first sense of différance, the second sense calls for a deferring of differing or to defer difference. In the passage quote at length above, Derrida tells us that because of heterogeneity, there is a call for an immediate action-to defer this difference-in order for us to act. In relation to the two laws of hospitality, there is already an immediate imperative to make certain decisions between the two, as implied in the passage. Does this mean that one should choose one over the other? For him, the decision-making process is not constituted by simply choosing between one of the two oppositions. ${ }^{71}$ One cannot simply

68 Ibid., 77.

${ }^{69}$ Derrida, Positions, 9.

${ }^{70}$ Cf. Derrida, "Différance," 8.

${ }^{71}$ This is important in understanding Derrida's philosophy. Deconstruction does not simply choose one of the two oppositions, rather it aims at striking the very root of these oppositions. Its goal is to disrupt their order or hierarchy.

(C) 2017 Franz Joseph C. Yoshiy II

https://www.kritike.org/journal/issue 21/yoshiy december2017.pdf

ISSN 1908-7330

(c) BY-NC-ND 
think of hospitality as unconditional or hospitality as conditional. In fact, one must take hospitality as conditional and unconditional.

The self-contradictory nature of these two laws, as mentioned in the third section, takes place at a certain threshold. The phenomenon of the threshold allows us to think clearly of the paradox in these two laws of hospitality. On one hand, "there is no hospitality without a threshold" would imply that the threshold is where the stranger/guest may be (unconditionally) welcomed, thus making hospitality possible. On the other hand, "there is no hospitality wherever there is a threshold" would mean that it is also the threshold that makes hospitality impossible since, it is here where the stranger/guest is (conditionally) welcomed-the threshold is where the conditions are announced before letting someone pass through it. To put it simply, the threshold itself bears this paradoxical law of hospitality.

This dilemma or paradox in the law of hospitality, however, is not meant to paralyze our decisions and actions. Derrida calls us to go beyond this contradiction within the threshold; to go beyond the opposition between conditional and unconditional. It is here where différance as deferment works as a call to a certain urgency to make a decision i.e. to think of a temporary (this is another sense of différance as deferment) solution/mediation between these two different movements of hospitality. To ease this problematic tension would necessitate an immediate solution, a compromise, a strategy. Derrida hints, "This is the double law of hospitality: to calculate the risks, yes, but without closing the door on the incalculable, that is, on the future and the foreigner."72 This is perhaps a succinct yet, an enlightening remark on the matter we are discussing. The host still welcomes the stranger/foreigner/guest, but, at the same time, calculates (or economize) the risk that may be brought about by the latter. This economization of risks takes place only once the master sets down the rules and/or the conditions of the house, which is why, in the fourth acceptation, Derrida's semantic investigation led him to the insight that the law of hospitality is also the law of the household or law of economics. From the following, we could surmise Derrida's point when he said that there is a need, an urgency with respect to the sense of différance as deferral. Despite the opposition between the two laws, they cannot be excluded from one another. One must deal with a certain economical calculation in mediating the two opposing laws, yet, one must still anticipate the incalculable stranger and the future that is to come.

After discerning these two senses of différance in the laws of hospitality, I would like to emphasize that they should be thought at the same time, just as Derrida took these two senses of différance together. Indeed, différance cannot be set aside in thinking of these paradoxical accounts. By positing the

72 Derrida, “The Principle of Hospitality," 6.

(C) 2017 Franz Joseph C. Yoshiy II

https://www.kritike.org/journal/issue 21/yoshiy december2017.pdf

ISSN 1908-7330

(cc) BY-NC-ND 


\section{DIFFÉRANCE IN DERRIDA'S ETHICS OF HOSPITALITY}

opposite movement of the conditional and unconditional, both senses of différance is already at work. But since différance already works as an economical concept, ${ }^{73}$ there is already a call to move beyond the differing concepts and begin to respond to the invitation to decide to be suggested by the contradiction. Thus, one is deferring the opposition through the employment of a certain economical strategy that does not choose between one of the two opposing forces, but rather sees that one of the forces carries within itself the other opposing force, thus making it impossible to pick one without picking the other. So that Derrida provides us with a subtle solution to this paradox: to come up with an urgent decisive resolution (if there is such a thing) to this contradiction in the laws of hospitality that is "to invent the best arrangements [dispositions], the least bad conditions, the most just legislation. This is necessary to avoid the perverse effects of an unlimited hospitality whose risks I tried to define." 74

\section{B. Différance within Hospitality: The Subject of Hospitality as Host/Hostage}

After dealing with the problem on the conditional and unconditional laws of hospitality, we are now set to discuss another prominent paradox within Derrida's discourse on hospitality: the subject of hospitality. I shall focus particularly on the dual role of the host as host and hostage, and the reversal of roles between the host and the guest [which in French are signified by a single term: hôte]. In any talks of hospitality, there are always two parties involved: that of the one offering hospitality or the host, and that of the one receiving it or the guest. The host is also the master of the house (or country, nation, State etc.). The guest, on the other hand, is the one who arrives, who seeks asylum, a refugee, a foreigner/stranger. To put it in Levinas' parlance (to whom Derrida owes some of his analysis on hospitality), the host is the subject, "I", self while the guest is the Other.

In the second acceptation of "we do not know what hospitality is," Derrida provides us with an account on how the subject of hospitality, the host becomes the hostage of the Other (the guest). He says:

We must also purse this terrifying and impassable strategy of the hostage in the direction of a modernity and a specific techno-politics of hostage taking ... of what Levinas calls the hostage, when he says that the exercise of ethical responsibility begins there where I am

73 "There is no economy without différance, it is the most general structure of economy." Derrida, Positions, 8.

${ }^{74}$ Derrida, "The Principle of Hospitality" 6. Italics mine.

(C) 2017 Franz Joseph C. Yoshiy II

https://www.kritike.org/journal/issue 21/yoshiy december2017.pdf

ISSN 1908-7330

(c) BY-NC-ND 
and must be the hostage of the other, delivered passively to the other before myself. 75

First, we must understand two things in this passage: what it means to be a hostage of the Other and ethical responsibility, the latter being made possible through the former. For Levinas, it is the Other who invites us to ethical responsibility. To be taken hostage (by the Other) means that the "the self ... is already substituted for the others." 76 The $I$ has taken the place of the Other, which means that even if the $I$, the host, in his mastery of the house, basks in his own power, he may still be taken hostage by the Other (the guest and stranger) i.e. "self as a 'hostage' [may be] persecuted by the other person." 77 This is because, the $I$ is as much as an Other as the Other is also an $I$. To this, Derrida writes "the other cannot be the other - of the same - except by being the same (as itself: ego), and the same cannot be the same (as itself: ego) except by being the other's other: alter ego." 78 There will always be a play of forces or power between the I and Other, the host and the guest. This substitution or being hostage to the Other is the rationale behind the reversal of roles between the host and the guest. ${ }^{79}$ The invited becomes the host, and the one inviting becomes the guest-indeed, there is a taking of places, a substitution. As Hutchen remarks, one the senses of responsibility in Levinas is "'responsibility' as responding for the other in the sense of substituting oneself for the other person in its responsibilities." 80 This reflects the phenomenon described by Derrida in his discussion of the reversal of roles: the host, whose responsibility lies within providing joy and comfort to the guest, becomes the guest, because his happiness depended on him offering hospitality to the guest. In short, the host who ought to fulfill the needs of his guest, turns into the guest fulfilling the needs of the host.

The subject, host or master, the $I$, or self, must then interrupt himself with this double-bind within his condition as the host and hostage. As a host, he must maintain his power and authority over the house, and at the same time acknowledge the fact that he becomes a hostage to the Other, guest, foreigner thus making him ethically responsible for them. This interruption

\footnotetext{
75 Derrida, "Hostipitality," 253.

${ }^{76}$ Levinas, Otherwise than Being, 118.

77 Benjamin Hutchens, Levinas: A Guide for the Perplexed (London \& New York: Continuum, 2004), 20.

${ }^{78}$ Derrida, “Violence and Metaphysics," 128.

${ }^{79}$ Although this reversal comes from Derrida's reading of Klossowski, he inserted the discussion of the hostage because, it is in this reversal of roles where we get the insight of the hostbecoming-the-hostage. And from here, he goes on to discuss the etymology of the hostage (through the Littre) and how it is related to ethics and politics (through Levinas). Cf. Derrida, "Hostipiltality," 252-253.

${ }^{80}$ Hutchens, Levinas: A Guide for the Perplexed, 19.
} 


\section{DIFFÉRANCE IN DERRIDA'S ETHICS OF HOSPITALITY}

or divide within the subject is a paradoxical moment in Derrida's ethics of hospitality. In fact, he notes that '[one] will understand nothing about hospitality if one does not understand what "interrupting oneself" might mean, the interruption of the self by the self as other.' ${ }^{81}$ Hence, I'll be taking this as my point of departure in discerning the movement of différance within the subject of hospitality.

In one of his interviews, Derrida remarks:

That is what is meant by self-interruption, which is another name for différance. Just as there would be no responsibility or decision without some selfinterruption, neither would there be any hospitality; as master and host, the self, in welcoming the other, must interrupt or divide himself or herself. This division is the condition of hospitality. ${ }^{82}$

This passage gives us a preliminary hint on how to respond to the problem at hand. Self-interruption is différance. To place this passage in context, Derrida was contrasting Edmund Husserl's phenomenology from Levinas' own version with regards to the Other. Unlike Husserl whose phenomenology relies on intuition in experiencing the Other, Levinas asserts that our relation with the Other-not simply as a phenomenologicalintuitional - must be an ethical one..$^{83}$ This for him is how self-interruption in phenomenology works.

But how exactly does différance work within the host's selfinterruption wherein "as master and host, the self, in welcoming the other, must interrupt or divide himself or herself." 84 We have already posited the two apparent conflicting forces in the subject of hospitality i.e. being host and hostage (of the Other). The tension or contradiction arises from the fact that, on one hand, the subject as host is constituted by the power he has over the household, the one who rules over the home. On the other hand, the subject as hostage takes the place of the Other or the guest when the latter finally arrives; he becomes hostage in the sense that his rule is displaced by the Other who comes.

Just as what we did in the previous section, allow me to discern différance in the subject by taking the two senses of différance i.e. differ-defer apart and attempt to trace the movement of each within the subject of

\footnotetext{
${ }^{81}$ Jacques Derrida, Adieu to Emmanuel Levinas, trans. by Pascale-Anne Brault and Michael Naas (Stanford, CA: Stanford University Press, 1999), 52. Italics mine.

${ }^{82}$ Derrida, "Hospitality, Justice and Responsibility," 81.

${ }^{83}$ Cf. Ibid.

${ }^{84}$ Ibid.

(C) 2017 Franz Joseph C. Yoshiy II

https://www.kritike.org/journal/issue 21/yoshiy december2017.pdf

ISSN 1908-7330
}

(c) BY-NC-ND 
hospitality as host and hostage. First, différance as differing is explicit within the subject as host-hostage by the mere fact that a host serves a different function from a hostage. In fact, it is quite uncanny that the master of the house be taken hostage by the guest. As was stipulated earlier, the host and the guest perform different functions. But in the situation of hostage-taking, the host substitutes the guest i.e. taking the latter's place. Thus, the heterogeneity that exists between host and hostage that is characterized by the separate function that they perform is the root of différance as differing. Host and hostage still belong to the realm of conceptual oppositions that is produced by différance.

Secondly, différance as deferring is the movement of delay, postponement, temporization, detour. The paradoxical instant of the subject being the host and hostage at the same time may be mediated through this sense of différance. How does this work? It was said that the host $(I)$ takes the place of the guest (the Other) by being the latter's hostage. The play of substitution here is similar to what is being signified by différance as deferral. This is to say that even before the guest's arrival, the host already carries within himself the fact that he is also a hostage (of the Other) because the host is not simply a sovereign $I$, exercising authority over everyone else. This very host or $I$ is also an Other to the guest, who also recognizes himself as an $I$. In short, "I am also essentially the other's other." ${ }^{85}$ For Derrida, this is the most economical gesture possible: for the $I$ to recognize that the Other is also an $I .{ }^{86}$ Again, one of the underlying significations of differrance as deferral is the provision of a strategy or economical calculation due to a certain demand for urgency. The urgency being demanded in hospitality is ethical - the call for the host to welcome and be responsible for the guest/Other who arrives. In substituting myself for the other, I am not only responsible to this Other, I am also responsible to the responsibilities of this Other..$^{87}$

Briefly, the movement of différance in the subject of hospitality lies within the tension between the subject as host and hostage. But just as we have said in the previous section that différance must not be thought apart as two separate movements: as differing on the one hand, and deferring on the other. As Derrida underscores, it is because of difference that there is deferral; it is this alterity that invites and urges us to respond, to employ a certain strategy that will mediate this alterity. ${ }^{88}$ For Levinas, this alterity is what invites the $I$ to a certain ethical responsibility-for it is only through ethics that the $I$ is

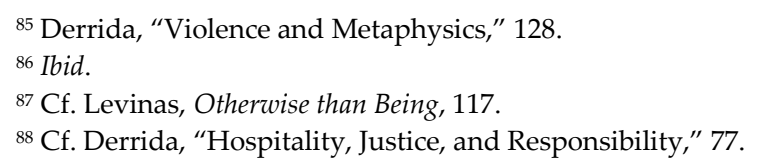

(c) 2017 Franz Joseph C. Yoshiy II https://www.kritike.org/journal/issue 21/yoshiy december2017.pdf ISSN 1908-7330 


\section{DIFFÉRANCE IN DERRIDA'S ETHICS OF HOSPITALITY}

mediated with the Other, ${ }^{89}$ that the $I$ is called to welcome and be held responsible for the Other, who takes the $I$ as hostage.

\section{Conclusion}

To sum up, allow me to share some words by Derrida from his work On Cosmopolitanism. He says:

Hospitality is culture itself and not simply one ethic amongst others. Insofar as it has to do with the ethos, that is, the residence, one's home, the familiar place of dwelling, inasmuch as it is a manner of being there, the manner in which we relate to ourselves and to others, to others as our own or as foreigners, ethics is hospitality; ethics is so thoroughly coextensive with the experience of hospitality. $\cdot{ }^{90}$

"Ethics is hospitality." If there is one phrase that would capture the essence of Derrida's thoughts on hospitality that is: being ethical is tantamount to being hospitable. Despite this ethical demand, the problems one may encounter in offering someone hospitality is still undeniable. I have presented this issue at the beginning of this project when I mentioned about the crisis our world faces today with regards to the sudden surge of refugees seeking asylum in other countries. Although, some have already welcomed refugees into their country, the recent attacks by radicals in some major cities in Europe (Paris, Belgium, etc.) opened the question on the extent of hospitality being offered to these people. The apparent difficulty of being hospitable to a foreigner/stranger and the probable risks that it may pose to one's self or country was thoroughly explored and discussed by Derrida.

By examining Derrida's notions of différance and his ethics of hospitality, indeed we can discern a movement of différance in hospitality through the paradoxical tension between the laws of unconditional and conditional hospitality. Because of the radical heterogeneity of these two laws i.e. they move into separate and conflicting movements, différance as differing inhabits these two opposing forces. By différance as deferring we do not mean, that our decision is paralyzed between these two conflicting movements. Rather, Derrida calls us to go beyond the opposition between conditional and unconditional. It is here where différance as deferment works as a call to a certain urgency to think of a provisional solution/mediation between these

${ }^{89} \mathrm{Ibid} ., 81$.

${ }^{90}$ Jacques Derrida, On Cosmopolitanism and Forgiveness, trans. by Mark Dooley and Michael Hughes (London: Routledge, 2001), 16-17.

(C) 2017 Franz Joseph C. Yoshiy II

https://www.kritike.org/journal/issue 21/yoshiy december2017.pdf

ISSN 1908-7330

(c) BY-NC-ND 
two different movements of hospitality. In other words, it also calls for an economical strategy that would reduce the potential threats of the unconditional, by stipulating conditions at the threshold, while remaining to be welcoming to the guest/stranger/Other.

Another paradox that unveils in Derrida's discussion of hospitality may be found within the subject of hospitality being a host and hostage (of the Other). This is considered to be a tension within itself since, the subject as host is the master and power that governs the house. He is the sovereign authority that lays down the laws of hospitality. But he is also a hostage of the Other i.e. the host is captivated by Other who demands ethical responsibility. The subject, then must interrupt or divide himself into being a host on the one hand, and being a hostage on the other. This interruption, according to Derrida, is none other than différance.

From here, I discerned the movement of différance in the following manner. First, différance as differing is already exhibited into the heterogeneity of the functions between the host and the hostage i.e. the host's role is different from of the hostage. This difference is what constitutes the différance (as differing) within the subject as host and hostage. Secondly, given the reversal and substitution of roles (between host and guest) brought about by hostage-taking, the host-taking-the-place-of-the-guest is the substitution that is similar to what is being pointed by différance as deferral. This is because the host, even before the guest arrives, already carries within himself the fact that he is also a hostage (of the Other). For Derrida, this is another economical gesture (which is an implicit meaning of différance as deferral) that the host must recognize that he is also an Other to the guest, inasmuch as the guest realizes that it is also an I. Hence, this economy that plays between the host and the guest, opens up the urgency and the ethical demand of hospitality i.e. the demand for the host to welcome the guest.

University of Santo Tomas, Philippines

\section{References}

Bernasconi, Robert, "The Trace of Levinas in Derrida," in Derrida and Différance, ed. by David Wood and Robert Bernasconi (Evanston, IL: Northwestern University Press, 1988).

Bonsall, Evan, "Are Syrian Refugees Really a Security Risk?" in Harvard Political Review (11 December 2015), <http://harvardpolitics.com Lunited-states/syrian-refugees-really-security-risk/>, 11 May 2016.

Bravo, Karen, "Do refugees have a 'right' to hospitality?" in The Conversation (5 November 2015), <http://theconversation.com/do-refugees-havea-right-to-hospitality-47629> 11 May 2016.

(C) 2017 Franz Joseph C. Yoshiy II

https://www.kritike.org/journal/issue 21/yoshiy december2017.pdf

ISSN 1908-7330

(cc) BY-NC-ND 


\section{DIFFÉRANCE IN DERRIDA'S ETHICS OF HOSPITALITY}

Derrida, Jacques, Acts of Religion, ed. by Gin Anidjar (New York: Routledge, 2002).

Adieu to Emmanuel Levinas, trans. Pascale-Anne Brault and Michael Naas (Stanford, CA: Stanford University Press, 1999). Aporias, trans. by Thomas Dutoit (Stanford, CA: Stanford University Press, 1993).

Deconstruction in a Nutshell: A Conversation with Jacques Derrida, ed. by John Caputo (New York, NY: Fordham University Press, 1997). "Derelictions of the Right to Justice," in Negotiations: Interventions and Interviews, 1971-2001, ed. and trans. by Elizabeth Rottenberg (Stanford: Stanford University Press, 2002).

"Différance" in Margins of Philosophy, trans. by Alan Bass (Great

Britain: The Harvester Press, 1982).

"Freud and the Scene of Writing" in Writing and Difference, trans.

by Alan Bass (Chicago: University of Chicago Press, 1978).

"Hospitality, Justice and Responsibility: A Dialogue with Jacques Derrida" in Questioning Ethics: Contemporary Debates in Philosophy, ed. by Richard Kearney and Mark Dooley (London: Routledge, 1999).

"Hostipitality" in Jacques Derrida: Basic Writings, trans. by Barry Stocker and Forbes Morlock, (London \& New York: Routledge, 2007). "Hostipitality," trans. by Barry Stocker and Forbes Morlock, in Angelaki: Journal of the Theoretical Humanities 5:3 (December 2000). Of Grammatology, corrected ed., trans. by Gayatri Chakravorty

Spivak, (Baltimore: The John Hopkins University Press).

Of Hospitality: Anne Dufourmantelle invites Jacques Derrida to

Respond, trans. by Rachel Bowlby (Stanford, CA: Stanford University Press, 2000).

. On Cosmopolitanism and Forgiveness, trans. by Mark Dooley and Michael Hughes (London: Routledge, 2001). Paper Machine, trans. by Rachel Bowlby (Stanford: Stanford

University Press, 2005). "The Principle of Hospitality" in Parallax 11:1 (2005).

"Violence and Metaphysics: An Essay on the Thought of Emmanuel Levinas" in Writing and Difference, trans. by Alan Bass (Chicago: University of Chicago Press, 1978).

Heidegger, Martin, Being and Time, trans. by John Macquarie and Edward Robinson (Oxford: Blackwell Publishers, 1962).

Hutchens, Benjamin, Levinas: A Guide for the Perplexed (London \& New York: Continuum, 2004).

(C) 2017 Franz Joseph C. Yoshiy II

https://www.kritike.org/journal/issue 21/yoshiy december2017.pdf

ISSN 1908-7330

(c) BY-NC-ND 
Johnson, Barbara, Translator's Introduction to Dissemination by Jacques Derrida, trans. by Barbara Johnson (London: The Athlone Press, 1981).

Kant, Immanuel, Perpetual Peace, in Political Writings, trans. by H.B. Nisbet and ed. H.S. Reiss (New York: Cambridge University Press, 1991).

Levinas, Emmanuel, Otherwise than Being, or Beyond Essence, trans. by Alphonso Lingis, (Dordrecht, The Netherlands: Kluwer Academic Publishers, 1991).

Norris, Christopher, Derrida (Cambridge, MA: Harvard University Press, 1987).

Patapan, Haig, "Leviathan's Children: On the Origins of Modern Hospitality," in Hospitality and World Politics, ed. by Gideon Baker (New York: Palgrave-Macmillan, 2013).

Peeters, Bennoît, Derrida: A Biography, trans. by Andre Brown (Malden: Polity Press, 2013).

de Saussure, Ferdinand, Course in General Linguistics, trans. by Wade Baskin and ed. by Perry Meisel and Haun Saussy (New York, NY: Columbia University Press, 2011).

"Seminars," in Derrida Seminars Translation Project (2009), $<$ http://derridaseminars.org/seminars.html>, 12 February 2017. 